NB! This is a pre-publication version of Naumov, N. (2019). The impact of robots, artificial intelligence, and service automation on service quality in hospitality. In Ivanov, S. \& Webster, C. (Eds) Robots, Artificial Intelligence and Service Automation in Travel, Tourism and Hospitality. Emerald Publishing, UK.

\title{
The impact of robots, artificial intelligence, and service automation on service quality and service experience in hospitality
}

\author{
Nikola Naumov \\ Department of Events, Tourism \& Hospitality \\ University of Northampton, Northampton, United Kingdom
}

Author note: Nikola (Nick) Naumov is a Senior Lecturer in Hospitality \& Tourism Management at the Department of Events, Tourism \& Hospitality at University of Northampton, United Kingdom. He has undergraduate and postgraduate degrees in tourism and hospitality management and a PhD in human geography completed at King's College London. His research interests include cultural and historical geographies of Eastern Europe, critical heritage studies, heritage tourism, service quality in hospitality, and innovation in tourism and hospitality management.

Correspondence address: Department of Events, Tourism \& Hospitality, Faculty of Business \& Law, University of Northampton, Waterside Campus, University Drive, Northampton, United Kingdom, NN1 5PH. E-mail: nick.naumov@northampton.ac.uk 


\title{
The impact of robots, artificial intelligence, and service automation on service quality and service experience in hospitality
}

\begin{abstract}
Purpose- The purpose of this chapter is to critically evaluate the implementation of technologies from the perspective of guest services, innovation and visitor experiences. The paper focuses on the value of robots, service automation and artificial intelligence in hospitality and examines their influence on service quality

Design/methodologylapproach- The chapter is a critical and conceptual overview of the emergence and implementation of robots, service automation and artificial intelligence in the hospitality with an emphasis on service, service quality and guest experience. A comprehensive overview of the academic literature of customer service and guest experience is combined with industry examples from various service operations in hospitality in order to examine the implementation of RAISA in the hospitality industry from a range of academic and practical viewpoints.
\end{abstract}

Findings- The chapter argues that despite the global acceptance of technologies in service industries in general and hospitality in particular, it remains difficult to find the right balance between digital and human interactions. In the context of service quality, the implementation of robots and service automation is increasingly important for gaining a competitive advantage, but the provision of more personalized guest experiences remains controversial.

Originality/value- The study provides a comprehensive and systematic review of RAISA in a hospitality context and examine their impacts on service quality. The chapter is a critical examination of the potential of RAISA to transform the service experience and raises some fundamental questions regarding the need for RAISA, its practical implications and impact over the understanding and measurement of service quality.

Keywords: Robots; service automation; artificial intelligence; service quality; guest experience; hospitality; 


\section{Introduction}

Hospitality refers to the practices of welcoming and entertaining guests and visitors (Walker, 2016). As Jones (2002, p.1) explains, hospitality services are primarily centred upon the provision of food, drinks and accommodation, and can take place within both commercial and non-commercial establishments (Lashley \& Morrison, 2000). Hotels and restaurants are traditionally what 'people think of the hospitality industry' (Barrows, Powers \& Reynolds, 2012, p.4) and customer service, and more specifically, the personal interaction between host and guests, is what essentially defines hospitality as an industry which is 'all about the people'.

However, the nature of hospitality in general, and the expectations of service and service quality in particular, have changed in the past few decades. A study by Meyer and Schwager (2007) has reported that the gap between what customers expect and what customers receive can be quite substantial. Their survey has found that while $80 \%$ of customers expect a superior experience, only $8 \%$ are actually satisfied with the outcome. The understanding of guest satisfaction has changed, largely driven by a number of factors, such as the widespread availability and distribution of information technologies. Today's digitally advanced consumers now expect more technologicallydriven products and personalised experiences (see for example, Enz \& Siguaw 2003; Kandampully, Zhang \& Jaakkola, 2018). In response to customer expectations and as a means to improve customer experience management, many hospitality businesses have started to adopt new approaches to service experience that involve service automation, mobile applications, artificial intelligence and even the involvement of service robots (Ivanov \& Webster, 2018; Ivanov, Webster \& Berezina, 2017)

This chapter focuses on the role of robots, artificial intelligence and service automation (RAISA) on service quality and service experience in hospitality. It seeks to explore the implementation of technologies from the perspective of guest services, innovation and visitor experiences. The chapter argues that the notion of service has been influenced by the ever-growing presence of technologies, integration of artificial intelligence and widespread popularity of service automation and as a result, service quality and guest satisfaction are no longer measured by 'how' service is provided but increasingly as 'what' is provided. A particular attention is given to the use and value of service automation and artificial intelligence in both business and social contexts and some concerns such as standardisation of services, overdependence on technologies and practical loss of personal touch are also critically discussed and analysed. 


\section{The influence of RAISA on service quality and service experience}

One of the most notable citations in the marketing literature is Peter Drucker's (1973, p.79) argument that 'to satisfy the customer is the mission and purpose of every business'. Within the context of hospitality, guest satisfaction has traditionally been measured by 'the extent of overall pleasure or contentment felt by the customers, resulting from the ability of the experience to fulfil the customer's desires, expectations and needs' (Qui, Ye, Bai \& Wang 2015, p.91). This desire to please the customer has been central for achieving service excellence focusing on the understanding and fulfilment of customers' needs and wants (Lashley, 2000).

This discourse, however, has changed with the emergence RAISA and more specifically, the applications of RAISA in travel, tourism and hospitality. As Ivanov (2019) demonstrates, the advance of RAISA now allows many businesses, including hospitality and tourism, to 'transform' their operations and subsequently reduce costs, stimulate productivity and improve the efficiency and reliability of the services they offer. Service automation and particularly, self service technologies, have long been used at airports (e.g. passenger services, e-passport gates), hotels (e.g. check-in/out_ or travel agencies to provide information (see for example, del Rio, Moctezuma, Conde, de Diego and Cabello, 2016; Kucukusta, Heung, \& Hui, 2014) and they improve the overall customers' experience (Bogicevic et al. 2017), reduce waiting times (Kattara \& El-Said, 2013) and decrease operational costs (Chathoth, 2007). Artificial intelligence provides opportunities for different types of specific analyses and research instruments but has particularly also gained a momentum with the increasingly important development of facial recognition (Del Rio et al. 2016). Robots, as demonstrated by Ivanov et al. (2019) \& Ivanov, Wester \& Berezina (2017), have been introduced in hospitality and tourism relatively later than other industries (e.g. engineering) but have increasingly been adopted by many hospitality and tourism businesses as they provide a cost-effective solution to many complex issues (Ivanov \& Webster, 2018) while also improving the customer experience (Kuo, Chen \& Tseng, 2017; Papathanassis, 2017).

The implementation of RAISA in hospitality has also changed our understanding of service and service quality. Figure 1 demonstrates how the extent of implementation of RAISA defines the changing perceptions of service quality and most importantly, drives the shift from customer service to 'memorable experience' and from 'personal, social interaction' to 'personal engagement in emotional and intellectual way'. The figure illustrates how RAISA have influenced the way service quality is perceived and measured showing the impact of RAISA on the conceptual understanding of service quality, the shift from customer service to 'guest experience' and most importantly, the move from 'process innovation' to 'product innovation'. First, RAISA have changed our understanding of service, more specifically, the way customer is dealt with and customers' expectations about efficiency and speed of service. 


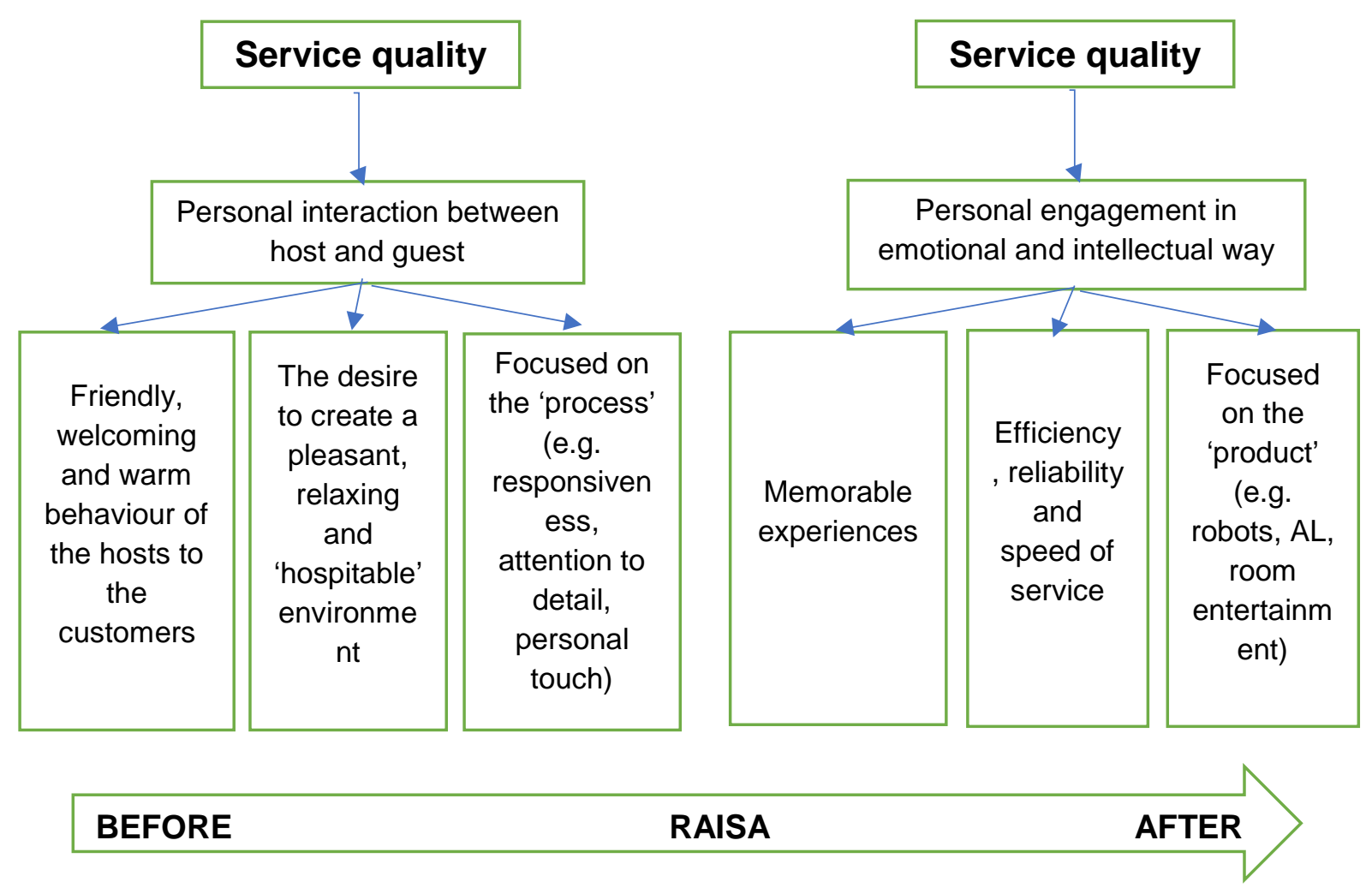

Figure 1. Impacts of RAISA on service quality in hospitality

Early theorists such as Burgess (1982, p.50) argue that hospitality should be understood as a social relationship and characterised by the friendly, welcoming and warm behaviour of the hosts to the customers. Such understanding defines service as the interaction between clients and customer-faced staff and argue that service quality is based on the quality of the process, i.e. threating the customer (e.g. personal touch, attention to details) and the ability of the hosts to create a pleasant, relaxing and 'hospitable' environment (see Blain \& Lashley, 2014; Brotherton, 2005; Brotherton \& Wood, 2008; Lashley, 2000). However, the emergence and distribution of technologies have challenged this understanding. As argued by Kandampully et al. (2018), service quality is no longer the result of the service encounters between 'hosts and guests' and greatly depends on greatly dependent on facility designs, in-room technologies and entertainment. The importance of providing not just a 'service' but 'memorable experience' has been central to the evolution of hospitality products and services (Bharwani and Jauhari, 2013; Hemmington, 2007; Melissen, van der Rest, Josephi \& Blomme, 2018; Sipe \& Testa, 2018) and in line with Pine \& Gilmore's (1998) idea of 'experience economy' - the move from a service-based economy to experience-based economy in which the financial success of a business lies in the creation of experiences instead of the delivery of services and products. As the work of Gartner (2014) empirically demonstrates, a great number of companies (89\% of his respondents) regard customer experience as their main tool for gaining a competitive 
advantage. The role of RAISA in this context is essential as technologies, personalised services and even service automation can be considered as integral components within the 'experiential nature' of hospitality. The work of Ruy and Jang (2018) on restaurant experiences and Johansson \& Naslund (2009) on cruise ship experiences further demonstrate this argument. The implementation of RAISA, as illustrated in Figure 1, has a key influence on the changing conceptual definition of service quality which is no longer understood as the outcome of a 'personal interaction' (service encounter) but 'personal engagement in emotional and intellectual way'.

Second, the implementation of RAISA has gradually influenced the way service quality is measured. Traditionally, service quality is examined through the lenses of Grönroos's dimensional model (1984) that measures the outcome (technical quality) and the process (functional quality) or Parasuraman, Zeithami and Berry's (1988) SERVQUAL based on five dimensions (tangibles, reliability, responsiveness, assurance and empathy). Both models put an emphasis on the notion of service and the interaction between 'hosts' and 'guests' and argue that the 'process' in the Grönroos 's model or 'responsiveness' in the SERVQUAL are key notions that contribute to the customer service (see also, Pijls-Hoekstra, Groen, Galetzka, \& Pruyn, 2017). If customer service and guest satisfaction have traditionally been measured by 'how' service is provided, then with the emergence of RAISA the focus has shifted to 'what' is provided. The need of innovations is essential, and many tourism and hospitality providers have focused their investment on both process and product innovations (see Bilgihan \& Nejad, 2010; Hall \& Williams, 2008). The guests' expectations and guests' perceptions of service quality are now much more focused on the need for technologies rather than the will to use technologies, and innovations such as in-room entertainment, keyless room entry and ease of using Artificial intelligence-enabled virtual agents are increasingly perceived as the new norms of guest satisfaction.

Examples of process innovations are the emergence of mobile applications and the widespread investment in service automation. Similarly to some travel businesses (see Moresan \& De Franco, 2016), hospitality firms have developed mobile applications to enhance the service experience. For example, Marriott Mobile App, among other functionalities, serves as a digital room key and allows guests to go directly to their room, instead of waiting to be checked in. Another example is Hyatt's Twitter Concierge that enables hotel guests to tweet concerns, special requests or ask for information 24/7 (see Robles, 2017).

The need of service automation has gradually emerged as a result of the customers' demands for efficiency, reliability and speed of service - some of the new variables of how service quality is measured, especially with the popularity of low-cost accommodation and fast food service providers. In order to respond to these demands, a constantly increasing number of hospitality providers continue to invest in technologies to make their service more efficient and reliable. For example, selfservice and service automation are now revolutionising the service industries, 
including hospitality, and have become the present age currency. A survey from The Center for Hospitality Research at Cornell University (Linton \& Kwortnik, 2015) has found that customers now prefer service automation for a wide variety of tasks and interactions (see also Giebelhausen, 2014). As a result, self-service kiosks have been introduced at hotel receptions enabling guests to check in and out while also creating their own room key (Oh, Jeong \& Baloglu, 2013). In the food industry, restaurants such as McDonald's and Wendy's have invested heavily in self-service kiosks and tablets used by customers to make orders, while others, such as Yo Sushi, have developed automated service mechanisms to serve their customers (see Klein, 2017; Ivanov, Webster \& Berezina, 2017).

Examples of product innovations are the increased popularity of guest room automation and the use of Artificial Intelligence (Al). For example, CitizenM in London has introduced the 'Moon Pad' - a room tablet that allows hotel guests to take a 'complete control' of their room, including room temperature, lightning, TV and even the window blinds (Nicholls, 2014). Similarly, the Shangri-La in Abu Dhabi has introduced a 'Guest Automation System' that automatically changes the status of the room from 'Occupied' to 'Vacant' when the guest is not present and changes the room temperature while providing valuable information to the reception desk (Hospitality Tech, 2017). Artificial Intelligence (AI) has also entered hospitality in many ways. Ever since the emergence of Apple's Siri and Amazon's Echo and Alexa, hospitality businesses have joined the race to delight their customers with new Al experiences. For example, Hilton's Connie, the first Al robot to work as a concierge have revolutionized our understanding of Al. Connie is based on IBM's Watson Al software and provides information about sites and visitor attractions, can answer simple questions and even learns from customer interactions to improve its future responses (Trejos, 2016). In Singapore, two Al-enabled virtual agents have been developed. SARA provides information and virtual assistance to customers and guests of Singapore (Niculescu et al.2014) while CLARA provides restaurant recommendations and other general information such as modes of transportation, sightseeing, etc. (D'Haro et al.2015).

One of the increasingly popular research domains is the emergence of robots in many hospitality operations and the human-robot interactions (Collins, 2015; Murphy, Hofacker \& Gretzel, 2017; Sun Tung \& Law, 2017). Robots have been introduced in many sectors and industries such as health care, manufacturing, packaging, food production (Angulo, Pfeiffer, Tellez \& Alenya, 2015; Blackman, 2013). They are increasingly emerging in hospitality and tourism. For example, Starwood Hotels have introduced a robotic butler called Boltr who has the capacity to deliver goods to customers (Crook, 2014) while Royal Caribbean have installed robots to work as bartenders on their flagship Quantum of the Seas (Golden, 2014). In Japan, Hennana Hotel has implemented functional trolleys robots to accompany hotel guests to their room while carrying their luggage and has been the first hotel to introduce humanoid robots at their reception desk (see Lewis-Kraus, 2016). Robots could be considered 
as both 'product' and 'process innovations'. They can be analysed in the context of process innovations as they address the contemporary needs of the current generation of digitally-advanced consumers while also providing cost-effective and cost-efficient options for the businesses (Ivanov \& Webster, 2018). From another perspective, the implementation of robots should also be analysed as a product innovation. For example, the T-rex humanoid robot at Henna-na Hotel in Japan have brought a huge popularity attracting thousands of curious visitors every year (Kikuchi, 2017). In Ghent, Belgium, the humanoid robot Mario, an 'employee' of The Marriott Hotel Ghent, has become a local celebrity. According to Annabelle Stevens, Marketing Manager of the hotel, Mario has 'stolen many hearts' and now works with school children, visit the local football club, give welcome/farewell speeches at events, and even works as a mascot! (Horecatrends, 2015).

This section has discussed the implementation of RAISA in hospitality and has examined the critical impact of RAISA on service and service experience. The main argument raised and sustained throughout the section is that the implementation of RAISA has changed the understanding of service, service quality and most importantly, how service quality is perceived and measured in the $21^{\text {st }}$ century. RAISA have contributed to the emergence of both process and product innovation and have gradually changed the expectations of customers to personally engage and interact as opposed to taking part in service encounters with their 'hosts'.

\section{RAISA and Service Quality - implications for the future}

As demonstrated in the previous section, the implementation of RAISA has illustrated the great potential of technologies in hospitality and their crucial role for providing a 'memorable experience'. As argued by Ivanov, Webster \& Berezina (2017), RAISA have the potential to completely overtake many entry-level jobs in hospitality and thus improve the cost-efficiency of the businesses in a long term. RAISA also have another important implication - they would allow trained employees to actually focus on providing a more personal guest experience. For example, Tom Beedon, General Manager of the Residence Inn in Los Angeles, explains how Wally, their relay robot, has improved the customer experience. He acknowledges that Wally is a guests' favourite and bring joy to their stay but focuses on its critical role to perform simple tasks in a very efficient way (e.g. delivering a Subway to a guest room). For him, having Wally saves much of precious time for the other employees who can focus more on the guest interactions and guest experience (Residence Inn, 2016).

Despite the notable advantages of RAISA, however, their implementation also raises many important questions regarding the notion of service quality. First, it is evident that RAISA could potentially improve the guest satisfaction levels at hospitality establishments where the importance of service is not particularly essential for their business. For instance, both Henn-na in Japan and the Residence Inn in Los Angeles are budget hotels which rely on successful integration of 'innovations' to attract customers. Further research is needed to explore the potential of RAISA to change 
the image of such hotels from 'low-cost' or 'budget' to 'comfort' and 'affordable'. Furthermore, empirical research is needed to study the customers' attitudes towards RAISA and more specifically, whether service automation, robots and artificial intelligence are considered 'process' or 'product' innovations.

Second, the spectacular extent of implementation of RAISA in hospitality during the past decade could make us think about the conceptual nature of service quality. With the rise of service innovation and popularity of service automation, the service encounters between 'hosts' and guest' could be a rare privilege reserved by a few hospitality providers which could afford to invest in the human interactions between staff and customers. The work of Pine \& Gilmore (1999) advocates the notion that service experience is essentially based on service encounters at different stages of the consumption process and the work of Bharwani \& Jauhari (2013), Bujisic et al. (2014), Lai, Hitchcock, Yang \& Lu (2018) and Nixon \& Rieple (2010) also highlight customer-employee relationships as the core element in providing a good customer experience. Therefore, despite the emergence and widespread implementation of RAISA, there is a room for personal interactions but are they the future of hospitality or rare privilege only reserved for selected establishments?

\section{Conclusion}

This chapter has focused on the increasingly important role of RAISA in hospitality and tourism. It has analysed the emergence and widespread of RAISA with a particular emphasis on their impact on guest services, guest experience and service innovation. The chapter argues that despite the global acceptance of technologies in service industries in general and hospitality in particular, it remains difficult to find the right balance between digital and human interactions. On one hand, the implementation of RAISA is undoubtedly cost-efficient, could attract new customer segments and can be regarded as both 'product innovation' and 'service innovation'. On another hand, although our understanding of service and service quality has changed with the emergence of RAISA, human-centered interactions are still essential to the notion of guest experience, largely because the inability of technologies (incl. humanoid robots) to convey human-centred experiences and pay attention to the detail.

In the context of service quality, the implementation of robots and service automation is increasingly important for gaining a competitive advantage, but the provision of more personalized guest experiences would still require a 'human touch'. What is more, with the speed of technologies and the willingness of hospitality business to further rely on RAISA, human-centered experiences could be the new currency of luxury hospitality and providing human-centred service could become an increasingly rare but highly valued product of the future. By all means, hospitality and tourism need RAISA - not only to provide a cost-effective solution to simple, entry-level operations but also to highlight the critical need of trained and educated employees. After all, hospitality is 
(and will be) an industry characterised by its intangible nature. Thus, satisfying the wide and diverse needs of guests require much more than a creative engineering idea.

Further research should explore the 'digitalisation' of guest experience and the extent to which RAISA assist personalisation and how it influences the guest experience from both product and process innovation perspectives. Future research themes could also explore the value of human-centred services in various parts of hospitality operations (e.g. front of house vs food and beverage) and the perceptions of different generations towards service quality and the extent to which RAISA play a critical role for the guest experience.

\section{References}

Bilgihan, A. \& Nejad, M. (2010). Innovation in hospitality and tourism industries. Journal of Hospitality \& Tourism Technology, 6 (3). DOI: http://dx.doi.org/10.1108/JHTT-08-20150033

Angulo, C., Pfeiffer, S., Tellez, R., \& Alenyà, G. (2015). Evaluating the Use of Robots to Enlarge AAL Services. Journal of Ambient Intelligence and Smart Environments, 7(3), 301-313.

Barrows, C., Powers,T. \& Reynolds, D. (2012). Introduction to the hospitality industry. Hoboken, NJ: John Wiley \& Sons.

Bharwani,S. \& Jauhari, V. (2013). An exploratory study of competencies required to co-create memorable customer experiences in the hospitality industry, International Journal of Contemporary Hospitality Management, 25 (6), 823-843.

Blackman, T.(2013). Care Robots for the Supermarket Shelf: A Product gap in Assistive Technologies. Ageing \& Society, 33(5), 763-781.

Blain, M. \& Lashley, C. (2014). Hospitableness: the new service metaphor? Developing an instrument for measuring hosting. Research in Hospitality Management, 4(1-2), 1-8.

Bogicevic, V., Bujisic, M., Bilgihan, A., Yang, W., \& Cobanoglu, C. (2017). The impact of traveler-focused airport technology on traveler satisfaction. Technological Forecasting and Social Change, 123, 351-361.

Brotherton, B. (2005). The nature of hospitality: customer perceptions and implications. Tourism and Hospitality Planning and Development 2, 139-153.

Brotherton, B. \& Wood, R. (2008). The nature and meanings of hospitality. In Brotherton, B. \& Wood, R. (Eds.) The SAGE Handbook of Hospitality Management (pp.37-61). London: Sage.

Bujisic, M., Wu, L., Mattila, A., \& Bilgihan, A. (2014). Not all smiles are created equal: investigating the effects of display authenticity and service relationship on customer tipping behaviour. International Journal of Contemporary Hospitality Management, 26(2), 293-306.

Burgess, J. (1982). Perspectives on Gift Exchange and Hospitable Behavior, International Journal of Hospitality Management 1(1), 49-57.

Chathoth, P. (2007). The impact of information technology on hotel operations, service management and transaction costs: A conceptual framework for full-service hotel firms. International Journal of Hospitality Management, 26(2), 395-408.

Collins, G. (2015). The Rise of Robotics in Hospitality. HITEC 2015 Special Report. Available at: http://hrm.nau.edu/images/uploads/hrm/Hitec2015-15SRw-Rise-of-Robotics-2223.pdf. Retrieved on 20 Feb 2017.

Crook, J. (2014). Starwood introduces robotic butlers at Aloft hotel in Cupertino. Available at: 
https://techcrunch.com/2014/08/13/starwood-introduces-robotic-butlers-at-aloft-hotel-in-paloaltol. Last Accessed 27 Dec 2017.

del Rio, J. S., Moctezuma, D., Conde, C., de Diego, I. M., \& Cabello, E. (2016). Automated border control e-gates and facial recognition systems. Computers \& Security, 62, 4972.

D'Haro, L., Kim, S., Yeo, K., Jiang, R., Niculescu, A.I., Banchs, R. \& Li, H. (2015) CLARA: a multifunctional virtual agent for conference support and touristic information. In: Geunbae Lee, G., Kook Kim, H., Jeong, M. and Kim, J. (Eds.) Natural Language Dialog Systems and Intelligent Assistants:.(pp.233-239). New York: Springer International Publishing.

Drucker, P. (1973). Managing the public service institution. Public Interest 33, 43-60.

Enz, C., \& Siguaw, J. (2003). Revisiting the best of the best: Innovations in hotel practice. Cornell Hotel and Restaurant Administration Quarterly, 44(5/6), 115-123

Gartner. (2014). Importance of customer experience is on the rise: marketing is on the hook, Available

at: https://www.gartner.com/doc/2853519/importance3customer3experience3rise3marke ting. Last Accessed on 17 Marc 2018.

Giebelhausen, M. (2014). Cyborg service: The unexpected effect of technology in the employee-guest exchange [Electronic version].Center for Hospitality Research Report, 14(19), 4-13.

Gilmore, J. \& Pine, B. (2002). Differentiating hospitality operations via experiences: Why selling services is not enough. Cornell Hotel and Restaurant Administration Quarterly, 43(3): 87-96.

Golden, F. (2014). Royal Caribbean's quantum of the seas features a bionic bar with robotic Bartenders. Available at: www.nydailynews.com/life-style/royal-caribbean-introducesrobot-bartenders-article-1.2015449. Last Accessed 21 October 2017.

Grönroos, C. (1984). A service quality model and its marketing implications. European Journal of Marketing, 18(4), 36-44.

Hemmington, N. (2007). From service to experience: Understanding and defining the hospitality business. The Service Industries Journal 27, 747-755.

Horecatrends(2015). Robot Mario, the new employee and mascot of the Marriott Hotel Ghent. Available at: httpp://www.horecatrends.com/en/robot-mario-the-new-employee-andmascot-of-the-marriott-hotel-ghent/. Last Accessed on 01 June 2018.

HospitalityTech (2017). 7 ways hotels are moving to an Automated Future. Available at: https://hospitalitytech.com/7-ways-hotels-are-moving-automated-future. Last accessed on $12^{\text {th }}$ April 2018.

Hall, C. \& Williams, A. (2008). Tourism and Innovation. London: Routledge.

Hwang, J. \& Seo, S. (2016). A critical review of research on customer experience management: Theoretical, methodological and cultural perspectives, International Journal of Contemporary Hospitality Management, 28(10), 2218-2246.

Ivanov, S. (2019) Ultimate transformation: How will automation technologies disrupt the travel, tourism and hospitality industries? Zeitschrift für Tourismuswissenschaft 11(1), (forthcoming).

Ivanov, S., Gretzel, U., Berezina, K., Sigala, M., \& Webster, C. (2019) Progress on robotics in hospitality and tourism: a review of the literature. Journal of Hospitality and Tourism Technology (forthcoming)

Ivanov, S., \& Webster, C. (2018). Adoption of robots, artificial intelligence and service automation by travel, tourism and hospitality companies - a cost-benefit analysis. In Marinov, V., Vodenska, M., Assenova, M. \& Dogramadjieva E. (Eds.) Traditions and Innovations in Contemporary Tourism. (pp.190-203). Newcastle upon Tyne, UK: Cambridge Scholars Publishing. 
Ivanov, S., Webster, C. \& Berezina, K. (2017). Adoption of Robots and Service Automation by Tourism and Hospitality Companies. Revista Turismo \& Desenvolvimento, 27/28, 1501-1517.

Johansson, M. \& Naslund, L. (2009). Welcome to paradise. Customer experience design and emotional labour on a cruise ship. International Journal of Work Organisation and Emotion, Vol.3 (1), pp. 40-55.

Jones, P. (2002). Introduction to hospitality operations: An indispensable guide to the industry. London: Cengage Learning.

Kandampully, J., Zhang, T. \& Jaakkola, E. (2018). Customer experience management in hospitality: a literature synthesis, new understanding, and research agenda, International Journal of Contemporary Hospitality Management, 30(1), 21-56.

Kattara, H. S., \& El-Said, O. A. (2013). Customers' preferences for new technology-based self-services versus human interaction services in hotels. Tourism and Hospitality Research, 13(2), 67-82.

Kikuchi. D. (2017). Strange' hotel, run by robots, opens near Tokyo; more to come. The Japan Times, 15 March 2017 [Online]. Available at:

https://www.japantimes.co.jp/news/2017/03/15/business/strange-hotel-run-by-robotsopens-near-tokyo-more-to-come/\#.W8UPIWhKhPY. Last accessed on: 01 Sep 2018.

Klein, J. (2017). Automation in the food service industry: Where we are now and what it means. Available at: https://medium.com/american-restaurant-supply/automation-in-the-foodservice-industry-where-are-we-now-and-what-does-it-mean-8a748e66ef3b.Last Accessed on: $17^{\text {th }}$ April 2018.

Kucukusta, D., Heung, V., \& Hui, S. (2014). Deploying self-service technology in luxury hotel brands: Perceptions of business travelers. Journal of Travel and Tourism Marketing, 31(1), 55-70.

Kuo, C.-M., Chen, L.-C., \& Tseng, C.-Y. (2017). Investigating an innovative service with hospitality robots. International Journal of Contemporary Hospitality Management, 29(5), 1305-1321.

Lai, I., Hitchcock, M.,Yang, T. \& Lu, T. (2018) Literature review on service quality in hospitality and tourism (1984-2014): Future directions and trends", International Journal of Contemporary Hospitality Management, 30(1), 114-159.

Lashley, C., \& Morrison, A. (2000). In search of Hospitality: Theoretical Perspectives and Debates. Oxford: Butterworth-Heinemann.

Lashley, C., Lynch, P. \& A. Morrison (2007). Hospitality: A Social Lens. Oxford: Elsevier.

Lewis-Kraus, G. (2016). Check in with the velociraptor at the world's first robot hotel. Available at: www.wired.com/2016/03/robot-henn-na-hotel-japan/. Last Accessed 01 June 2018.

Linton, H., \& Kwortnik, R. J. (2015). The mobile revolution is here: are you ready? Cornell Hospitality Reports,15(6), 6-18.

Melissen, F., van der Rest, J., Josephi, S. \& Blomme, R. (2018). Hospitality Experience: An Introduction to Hospitality Management. $2^{\text {nd }}$ Edn. Groningen/Utrecht: Noordhoff Uitgevers bv.

Meyer, C. and Schwager, A. (2007). Understanding customer experience. Harvard Business Review. 85(2), 116-126.

Morosan, C. \& De Franco, A. (2016). Co-creating value in hotels using mobile devices: A conceptual model with empirical validation. International Journal of Hospitality Management, 52, 131-142.

Murphy, J., Hofacker, C \& Gretzel, U. (2017) Robots in Hospitality \& Tourism: A Research Agenda. Paper Presented at ENTER 2017, 24-26 June 2017, Rome, Italy.

Nicholls, L. (2014) Customer-focused technology. High-tech hospitality in action. Available at: http://www.bighospitality.co.uk/Business/Customer-focused-technology-High-techhospitality-in-action. Last accessed on 15 ${ }^{\text {th }}$ Nov 2017. 
Niculescu, A., Jiang, R., Kim, S., Yeo, K., D’Haro I,,Niswar,A.\& Banchs,R. (2014) SARA: Singapore's automated responsive assistant, a multimodal dialogue system for touristic information. In Awan, I., Younas, M., Franch, X. and Quer, C. (Eds) Mobile Web Information Systems. (pp.153-164). New York: Springer International Publishing.

Nixon, N. \& Rieple, A. (2010). Luxury redesigned: how the Ritz Carlton uses experiential service design to position abundance in times of scarcity. Design Management Journal, 5(1), 40-49.

Oh, H., Jeong, M. \& Baloglu, S. (2013) Tourists' adoption of self-service technologies at resort hotels. Journal of Business Research, 66(6), 692-699.

Papathanassis, A. (2017). R-Tourism: Introducing the Potential Impact of Robotics and Service Automation in Tourism. Ovidius University Annals, Series Economic Sciences, 17(1), 211-216

Parasuraman, A., Zeithaml, V. \& Berry, L. (1988). SERQUAL: A multiple-item scale for measuring consumer perceptions of service quality. Journal of Retailing, 64 Spring: $12-40$

Pijls-Hoekstra, R., Groen, B., Galetzka, M. \& Pruyn, A. (2017). Measuring the experience of hospitality: Scale development and validation. International Journal of Hospitality Management 67, 125-133.

Pine, B. \& Gilmore, J. (1999). The experience economy, Boston, MA: Harvard Business School Press.

Residence Inn (2016). Residence Inn LAX/Relay Robot Case Study. Available at: https://www.youtube.com/watch?v=LkhkwiAQ2n4. Last accessed on: 01 Apr 2018.

Robles, P. (2009). Hyatt's Twitter Concierge: good idea, wrong platform. Available at: https://www.econsultancy.com/blog/3895-hyatts-twitter-concierge-good-idea-wrongplatform. Last Accessed on: $15^{\text {th }}$ April 2018.

Qiu, H., Ye, B., Bai, B. \& Wang, W. (2015). Do the Roles of Switching Barriers on Customer Loyalty Vary for Different Types of Hotels? International Journal of Hospitality Management, 46, 89-98.

Ryu, K. and Jang, S. (2008). DINESCAPE: A scale for customers' perception of dining environments, Journal of Foodservice Business Research, 11 (1), 2-22.

StayNTouch (2016) Why Guests Crave Service Automations. Available at: http://www.stayntouch.com/blog/why-its-important-to-provide-the-choice-ofautomation-to-guests. Last Accessed on 10 th $^{\text {th }}$ March 2018.

Sipe, L. \& Testa, M. (2018). From Satisfied to Memorable: An Empirical Study of Service and Experience Dimensions on Guest Outcomes in the Hospitality Industry. Journal of Hospitality Marketing \& Management, 27(2), 178-195.

Sun Tung, V. \& Law, R. (2017). The potential for tourism and hospitality experience research in human-robot interactions. International Journal of Contemporary Hospitality Management, 29(10), 2498-2513.

Taylor, J., Bing, M., Reynolds, D., Davison, K. \& Ruetzler, T. (2018). Motivation and personal involvement leading to wine consumption. International Journal of Contemporary Hospitality Management, 30(2), 702-719.

Trejos, N. (2016). Introducing Connie, Hilton's New robot concierge. Available at: https://eu.usatoday.com/story/travel/roadwarriorvoices/2016/03/09/introducingconnie-hiltons-new-robot-concierge/81525924/. Last Accessed on 15 ${ }^{\text {th }}$ March 2018.

Walker, J. (2016). Introduction to Hospitality. Harlow, UK: Pearson Education. 